\title{
Prognostic significance of serum iron levels in cases of Japanese encephalitis
}

\author{
M. Bharadwaj, V. Prakash, A. Mathur and U.C. Chaturvedi
}

Postgraduate Department of Microbiology, K.G. Medical College, Lucknow-226.003, India

\begin{abstract}
Summary: Forty-one children with acute laboratory confirmed Japanese encephalitis were studied. Serum iron concentrations were consistently low following Japanese encephalitis virus infection, with the levels being of prognostic significance.
\end{abstract}

\section{Introduction}

Japanese encephalitis virus (JEV), an arthropod borne flavivirus ${ }^{1}$ is one of the major causes of acute encephalitis ${ }^{2}$ and is responsible for thousands of cases each year, mainly in the Far East. ${ }^{3}$ In Uttar Pradesh, India. Japanese encephalitis is probably endemic $^{4}$ with high mortality. ${ }^{5}$ Little is known about the pathogenesis of infection in man.

Alteration in iron metabolism is an accompaniment to a variety of infections and inflammatory states. ${ }^{6}$ Pekarek et al. ${ }^{7}$ have demonstrated a significant fall in serum iron concentration before the onset of illness in volunteers exposed to bacterial infection and in asymptomatic subjects after exposure to live attenuated Venezuelan equine encephalomyelitis virus vaccine. ${ }^{8} \mathrm{~A}$ reduction in plasma iron has been shown to occur during a number of bacterial infections ${ }^{9}$ or after injection of bacterial lipopolysaccharide. ${ }^{10}$ This response to infections has been regarded as a host-mediated attempt to control the infection by limiting the iron availability to organisms. ${ }^{11}$

Recent studies in mice revealed a low serum iron concentration following JEV infection ${ }^{12}$ caused by the action of macrophage derived factor, which blocks the release of iron from splenic reticuloendothelial cells. ${ }^{13}$ To date no information is available on changes in iron levels during JEV infection in man.

\section{Patients and methods}

Ninety-five children with acute encephalitic illness (acute, nontransient alteration of consciousness with or without fever or other neurological symptoms) were admitted to G.M. and Associated

Correspondence: Professor Asha Mathur, D.C.P., M.D., F.R.C.Path(Lond.)

Accepted: 15 October 1990
Hospital, Lucknow, India between July to December 1989. Their age was between 3 to 12 years. The duration of illness on admission was less than 5 days. Forty-one children had one or more indicators of JEV infection. A diagnosis of JEV infection was confirmed by virus isolation from cerebrospinal fluid (CSF), by demonstration of JEV antigen in CSF cells (JEV monoclonal antibody was provided by Dr E.A. Gould, Oxford, UK), by demonstration of anti-JEV IgM in CSF or by rising antibody titres against JEV in paired sera as described previously. ${ }^{4,5}$ The control group comprised of 21 normal healthy children of matched age and sex. All the children were bled in the morning at approximately the same time. Blood was collected in polyethylene syringes and test tubes to prevent iron contamination. Blood specimens could only be collected once in fatal cases, but in others at 1-4 days, 5-8 days and 9-12 days of illness, on the basis of first day of appearance of fever.

Serum iron and total iron binding capacity were detected colorimetrically according to the modified method of Beale et al..$^{14}$ with bathophenanthroline sulphate as the colour reagent as described earlier. ${ }^{9}$ The total protein and albumin in serum were measured colorimetrically. ${ }^{15}$

\section{Results}

Forty-one children aged 3 to 12 years having confirmed Japanese encephalitis were included in the study. Thirteen children were severely ill and rapidly progressed to coma and death within 48 hours of admission. Twenty-eight children survived.

The serum iron levels in JEV patients and control groups are presented in Table I. The mean serum iron level of $34 \pm 3 \mu \mathrm{g} / \mathrm{dl}$ in fatal Japanese encephalitis patients was significantly less $(P<0.001)$ than the mean $(82 \pm 9 \mu \mathrm{g} / \mathrm{dl})$ observed in normal 
healthy controls. There was no significant difference in serum iron values in the initial stage of illness in patients with non-fatal encephalitis when compared with control (Table I). In these patients, the later serum iron levels were $40 \pm 3 \mu \mathrm{g} / \mathrm{dl}$ $(P<0.001)$ between 5 to 8 days and $48 \pm 4 \mu \mathrm{g} / \mathrm{dl}$ between 9 to 12 days of illness. The total iron binding capacities in JE patients was similar to that of control children.

There was a transient decrease in the mean haemoglobin values in the non-fatal encephalitis patients between 5 to 8 days $(7.0 \pm 1.5 \mathrm{~g} / \mathrm{dl})$ of illness when compared with control $(11.5 \pm 2.5 \mathrm{~g} / \mathrm{dl})$. No significant difference was noted in haemoglobin values in cases of fatal encephalitis and the controls $(P>0.05)$. The total serum protein and albumin did not show any deviation from normal values (Table II).

\section{Discussion}

The initial response of serum iron concentration after fatal JEV infection was a decrease. Significant decrease in serum iron concentration was observed within $48 \mathrm{~h}$ in severely ill fatal patients. The investigations revealed that the serum iron levels did not show any marked alterations in the initial $\overline{ }$ period in non-fatal encephalitis patients. Thus the $c$ reduction in serum iron level was directly related to the severity of illness. Out of the 13 fatal $\mathrm{JE} \stackrel{\text { ? }}{\rightarrow}$ patients, in 5 the $\mathrm{JE}$ virus was isolated from CSFO and in 8 patients JE virus-specific antigen in large 흐 numbers of CSF cells was detected by indirect $\frac{\bar{\omega}}{\overline{2}}$ immunofluorescence while no virus was isolated $\stackrel{\Phi}{\Omega}$ from CSF in non-fatal cases and the immunofluorescence positive cells were few in CSF (data not ${ }^{\text {s }}$ included).

Following JEV infection hypoferraemia with $\overrightarrow{\vec{\omega}}$ transient anaemia has been demonstrated in mice. $\stackrel{\omega}{\circ}$ The degree of decrease was associated with the 8 severity of infection. ${ }^{9}$ The hypoferraemia is achiev- 3 . ed by a block in the release of iron from reticulo- $\sigma$ endothelial cells in spleen by a macrophage derived factor. ${ }^{10}$

The serum iron level decreases during inflam- i mation $^{6}$ which causes reduction in synthesis of $\underset{\forall}{ }$ hepatic export proteins, albumin and transferrin, 을 resulting in hypoferraemia. Simultaneously, the release occurs of certain acute phase proteins $?$

Table I Time course relationship of serum iron changes to severity of clinical illness in confirmed cases of Japane encephalitis

\begin{tabular}{|c|c|c|c|c|c|c|c|c|c|c|c|}
\hline \multirow[b]{2}{*}{ Subjects } & \multirow{2}{*}{\multicolumn{2}{|c|}{$\begin{array}{c}\text { Total } \\
\text { number }\end{array}$}} & \multicolumn{3}{|c|}{$1-4$} & \multicolumn{3}{|c|}{$\begin{array}{c}\text { Days of illness } \\
5-8\end{array}$} & \multicolumn{3}{|c|}{$9-12$} \\
\hline & & & $\begin{array}{c}\text { Serum } \\
\text { iron } \\
\mu g / d l\end{array}$ & $\begin{array}{l}T I B C \\
\mu g / d l\end{array}$ & $\begin{array}{c}\% \text { iron } \\
\text { saturation }\end{array}$ & $\begin{array}{c}\text { Serum } \\
\text { iron } \\
\mu g / d l\end{array}$ & $\begin{array}{l}T I B C \\
\mu g / d l\end{array}$ & $\begin{array}{l}\% \text { iron } \\
\text { saturation }\end{array}$ & $\begin{array}{c}\text { Serum } \\
\text { iron } \\
\mu g / d l\end{array}$ & $\begin{array}{l}T I B C \\
\mu g / d l\end{array}$ & $\begin{array}{c}\% \text { iron } \\
\text { saturation }\end{array}$ \\
\hline $\begin{array}{l}\text { Control } \\
\text { Non fatal }\end{array}$ & 14 & $\begin{array}{l}7 \\
7\end{array}$ & $\begin{array}{l}82 \pm 19 \\
71 \pm 17^{* *}\end{array}$ & $\begin{array}{l}263 \pm 18 \\
258 \pm 13^{*}\end{array}$ & $\begin{array}{l}31.17 \\
27.51\end{array}$ & $\begin{array}{l}79 \pm 4 \\
40 \pm 3^{* * *}\end{array}$ & $\begin{array}{l}252 \pm 9 \\
261 \pm 11^{*}\end{array}$ & $\begin{array}{l}31.34 \\
15.32\end{array}$ & $\begin{array}{l}84 \pm 8 \\
48 \pm 4^{* * *}\end{array}$ & $\begin{array}{l}256 \pm 14 \\
248 \pm 12\end{array}$ & $\begin{array}{l}32.81 \\
19.35\end{array}$ \\
\hline Fatal & 10 & 3 & $34 \pm 3^{* * *}$ & $251 \pm 17^{*}$ & 13.54 & - & - & - & - & - & - \\
\hline
\end{tabular}

TIBC $=$ total iron binding capacity. Mean value \pm s.d. is presented for each group. ${ }^{*} P<0.05 ; * * P<0.01 ;$ $* * * P<0.001$.

Table II Haemoglobin and total protein levels in confirmed patients with Japanese encephalitis virus and controls

\begin{tabular}{|c|c|c|c|c|c|c|c|}
\hline \multirow[b]{2}{*}{ Subjects } & \multirow{2}{*}{$\begin{array}{c}\text { Total } \\
\text { number }\end{array}$} & \multicolumn{2}{|r|}{$1-4$} & \multicolumn{2}{|c|}{$\begin{array}{c}\text { Days of illness } \\
5-8\end{array}$} & \multicolumn{2}{|c|}{$9-12$} \\
\hline & & $H b g / d l$ & T.Pr./Alb g/dl & $H b g / d l$ & T.Pr./Alb g/dl & $H b g / d l$ & T.Pr./Alb g/dl \\
\hline Control & 21 & $10.8 \pm 2.3$ & $\begin{array}{l}6.2 \pm 1 / \\
3.6 \pm 0.5\end{array}$ & $11.5 \pm 2.5$ & $\begin{array}{l}6.8 \pm 1.2 / \\
3.1 \pm 0.5\end{array}$ & $11.0 \pm 1.8$ & $\begin{array}{l}6.4 \pm 1 / \\
3.8 \pm 0.6\end{array}$ \\
\hline Nonfatal & 28 & $10.0 \pm 2.5^{*}$ & $\begin{array}{l}7.1 \pm 1.2^{*} / \\
3.8 \pm 0.7^{* *}\end{array}$ & $7.0 \pm 1.5^{* * *}$ & $\begin{array}{l}7.4 \pm 1.4^{*} / \\
3.9 \pm 0.5^{*}\end{array}$ & $9.0 \pm 1.5^{* * *}$ & $\begin{array}{l}6.9 \pm 1.2^{*} / \\
3.9 \pm 0.4^{*}\end{array}$ \\
\hline Fatal & 13 & $9.2 \pm 1.4^{* *}$ & $\begin{array}{l}6.8 \pm 1.1^{*} / \\
3.5 \pm 0.9^{*}\end{array}$ & - & $-\quad-$ & - & $\begin{array}{c}0.9-0.4 \\
-\quad-\end{array}$ \\
\hline
\end{tabular}

$\mathrm{Hb}$ - haemoglobin; T.Pr. - total protein; Alb - albumin; mean value \pm s.d is presented for each group. The data were analysed by Student's $t$ test. ${ }^{*} P>0.05 ;{ }^{* *} P<0.01 ;{ }^{* *} P<0.001$. 
formed by activated monocytes of liver with their increased concentration in serum. ${ }^{16} \mathrm{~A}$ fall in serum iron due to alterations in plasma proteins is a general marker of inflammation. In the present study there was no apparent alteration in total protein or albumin, which suggests that there was no change in protein synthesis in liver during JEV infection.

\section{References}

1. Westaway, E.G., Brinton, M.A., Gaidamovich, S.Ya. et al. Flaviviridae. Intervirology 1985, 24: 183-192.

2. Shope, R. Medical significance of Togaviruses: an overview of diseases in man and in domestic and wild vertebrate animals. In: Schlesinger, R.W. (ed.) The Togaviruses. Academic Press, New York, 1980, pp. 47-82.

3. Monath, T.P. Pathobiology of flaviviruses. In: Schlesinger, S. \& Schlesinger, M. (eds) The Togaviruses and Flaviviruses Plenum Press, New York, 1986.

4. Kumar, R., Mathur, A., Kumar, A., Sharma, S., Saksena, P.N. \& Chaturvedi, U.C. Japanese encephalitis. An important cause of acute childhood encephalopathy in Lucknow. India Post Med J 1988, 64: 18-22.

5. Mathur, A., Kumar, R., Sharma, S., Kulshreshtha, R., Kumar, A. \& Chaturvedi, U.C. Rapid diagnosis of Japanese encephalitis by immunofluorescent examination of cerebrospinal fluid. Indian J Med Res 1990, A91: 1-4.

6. Huebers, H.A. \& Finch, G.A. The physiology of transferrin and transferrin receptors. Physiol Rev 1987, 67: 520-582.

7. Pekarek, R.S., Bostian, K.A., Bartelloni, P.J., Calia, F.M. \& Beisel, W.R. The effects of Franciselia tularensis on iron metabolism in man. Am J Med Sci 1969, 258: 12-25.

8. Pekarek, R.S., Burghen, G.A., Bartelloni, P.J., Calia, F.M., Bostian, K.A. \& Beisel, W.R. The effect of live attenuated Venezuelan equine encephalomyelitis virus vaccine on serum iron zinc and copper concentrations in man. $J$ Lab Clin Med 1970, 76: 293-303.

9. Finkelstein, R.A., Sciortino, C.V. \& McIntosh, N.A. Role of iron in microbe host interactions. Rev Infect Dis 1983, 5: 759-777.
Once the specific diagnosis of $\mathrm{JE}$ in patients has been made on the day of admission either by indirect immunofluorescence examination of cells in $\mathrm{CSF}^{5}$ or by estimation of IgM antibodies in $\mathrm{CSF},{ }^{17}$ it may now be possible to predict the prognosis of $\mathrm{JE}$ in confirmed cases by measuring the serum iron on the same day.

10. Kampschmidt, R.F., Pulliam, L.A. \& Upchurch, H.F. The activity of partially purified leucocytic endogenous mediator in endotoxin resistant C3H/HEJ mice. $J$ Lab Clin Med 1980 , 95: 616-623.

11. Weinberg, E.D. Iron withholding: a defence against infection and neoplasia. Physiol Rev 1984, 64: 65-102.

12. Mathur, A., Bharadwaj, M. \& Chaturvedi, U.C. Alterations in iron levels in Japanese encephalitis virus infection. $J$ Exp Pathol 1990, 71: 307-312.

13. Bharadwaj, M., Khanna, N., Mathur, A. \& Chaturvedi, U.C. Effect of macrophage derived factor in JEV induced hypoferremia in mice. Clin Exp Immunol 1991, 83 (in press).

14. Beale, R.N., Bostrom, J.O. \& Taylor, R.F. Improved rapid methods for the determination of iron content and binding capacity of serum. J Clin Pathol 1962, 15: 156-160.

15. Gowenlock, A.H., McMurray, J.R. \& McLauchlan, D.N. (eds) Varley's Practical Clinical Biochemistry, 6th edition. Heinemann Medical Books, London, 1988, pp. 407-411.

16. Schaechter, M., Medoff, G. \& Schlesinger, D. In: Mechanisms of Microbial Disease. Williams and Wilkins, Baltimore, 1989, p. 819 .

17. Burke, D.S., Nisalak, A., Ussery, M.A., Laorakpongse, T. \& Chantavibul, S. Kinetics of IgM in IgG responses to Japanese encephalitis virus in human serum and cerebrospinal fluid. $J$ Infect Dis 1985, 15: 1093-1099. 